\title{
Erratum to: Site effect assessment using KiK-net data: part 2-site amplification prediction equation based on $\mathbf{f}_{\mathbf{0}}$ and Vsz
}

\author{
Héloïse Cadet · Pierre-Yves Bard • \\ Anne-Marie Duval • Etienne Bertrand
}

Published online: 19 October 2011

(C) Springer Science+Business Media B.V. 2011

\section{Erratum to: Bull Earthquake Eng DOI 10.1007/s10518-011-9298-7}

Unfortunately the name of the first author was captured incorrectly in this article. It should be Héloïse Cadet, not Cadet Héloïse.

The online version of the original article can be found under doi:10.1007/s10518-011-9298-7.

H. Cadet · P.-Y. Bard

Institut des Sciences de la Terre (ISTerre), CNRS, University Joseph Fourier, Grenoble, IFSTTAR, BP 53, 38041 Grenoble Cedex 9, France

H. Cadet · A.-M. Duval · E. Bertrand

CETE Méditerrannée, Centre d'études Techniques de l'équipement, Regional Laboratory of Nice, 56 bd Stalingrad, 06359 Nice Cedex 4, France

H. Cadet $(\varangle)$

Institute of Engineering Seismology and Earthquake Engineering (ITSAK), Cosmos Office,

Agios Georgiou 5, Thessaloniki, Greece

e-mail: hcadet@obs.ujf-grenoble.fr

H. Cadet

A.D.R.G.T. (SAGE), Association for the Development of Research in Land Slides, 2 rue de la condamine, Gières, France 